\title{
SIGNIFICANCE OF PLOIDY CHANGES IN ADULT ACUTE LYMPHOBLASTIC LEUKEMIA
}

\author{
Zotova O. ${ }^{1}$, Lukianova A. ${ }^{2}$, Valchuk M. ${ }^{1}$, Karol Y. ${ }^{3}$, \\ Kostyk K. ${ }^{1}$, Shalay O. ${ }^{1}$, Loginsky V. ${ }^{1}$ \\ ${ }^{I}$ SI «Institute of Blood Pathology and Transfusion Medicine of NAMS of Ukraine», \\ Lviv, Ukraine \\ ${ }^{2}$ Medical Biology Centre «Genom», Kyiv, Ukraine \\ ${ }^{3}$ CNE «Municipal Clinical Hospital No. 5», Lviv, Ukraine
}

\begin{abstract}
Introduction. Acute lymphoblastic leukemia (ALL) is characterized by different clinical courses and different sensitivity to therapy. Taking into consideration their significant prevalence, an intensive search for new prognostic criteria is conducted that may determine individual prognosis and define the most appropriate treatment approach for patients with ALL.
\end{abstract}

The aim was to detect the diagnostic and prognostic significance of chromosome set changes in patients with ALL.

Materials and methods. Cytogenetic investigations of peripheral blood (PB) and/or bone marrow (BM) cells from 48 patients with ALL (range: 18-82 years, 24 males and 24 females) were performed. The methods of conventional cytogenetics and fluorescence in situ hybridization (FISH) were used. Cytogenetic methods were performed using standard techniques and karyotypes were described according to the International System for Human Cytogenetic Nomenclature (ISCN, 2016).

Results. Cytogenetic abnormalities of various kinds were found, namely t(9;22)(q34;q11), BCR/ABL gene, 11q23 rearrangements, t(4;11)(q21;q23), del(17p), del(7q), hyperdiploidy, hypodiploidy and others, in $68.8 \%$ patients with ALL. Some genetic abnormalities (BCR/ABL fusion gene) were detected by the molecular genetic method (FISH). High hyperdiploidy (51-67 chromosomes) was found in 5 (10.4\%) patients with ALL. Hypodiploidy (24-44 chromosomes) was found in 2 (4.2\%) cases. The type of ALL was confirmed according to the WHO classification (2016) in $35.4 \%$ of patients. Taking into consideration the identified abnormalities patients with ALL were classified into cytogenetic prognostic groups: the group of patients with adverse prognosis factors $(35.4 \%)(t(9 ; 22)(q 34 ; q 11), t(4 ; 11)(q 21 ; q 23)$, hypodiploidy, complex karyotype ( $\geq 3$ abnormalities)), the intermediate prognostic group without significant cytogenetic markers $(56.3 \%)$ and the group of patients with favorable prognostic markers $(8.3 \%)(t(12 ; 21)(p 13 ; q 22)$, high hyperdiploidy), which allows choosing the most appropriate treatment approach for them.

Conclusions. In our investigation, chromosomal abnormalities of various kinds were found in $68.8 \%$ of patients with ALL. Taking into consideration the identified 
abnormalities ALL patients were classified into three cytogenetic prognostic groups. The frequency of high hyperdiploidy and hypodiploidy was $10.4 \%$ and $4.2 \%$, respectively. Cytogenetic investigations should be included in the standard examination of patients with ALL for diagnosis, prognosis and selection of the optimal treatment strategy. Besides the analysis of differential banding pattern chromosomes for patients with ALL, it is necessary to apply molecular genetic studies, namely FISH and polymerase chain reaction (PCR).

Keywords: acute lymphoblastic leukemia, karyotype, cytogenetic abnormalities, diagnosis, prognosis.

Competing interests: the authors declare no conflict of interests in relation to this article.

Financing resources: research had no industry funding.

\title{
ЗНАЧЕННЯ ЗМІН ПЛОЇДНОСТІ ПРИ ГОСТРИХ ЛІМФОБЛАСТНИХ ЛЕЙКЕМІЯХ У ДОРОСЛИХ
}

\author{
Зотова О. В. ${ }^{1}$, Лук'янова А. С. ${ }^{2}$, Вальчук М. О. ${ }^{1}$, Кароль Ю. С. ${ }^{3}$, \\ Костик Х. Я. ${ }^{1}$, Шалай О. О. ${ }^{1}$, Логінський В. С. ${ }^{1}$ \\ ${ }^{I}$ ДУ «Інститут патологї крові та трансфузійної медицини НАМН Украӥни», \\ Львів, Украӥна \\ ${ }^{2}$ Медико-біологічний центр «Геном», Київ, Украӥна \\ ${ }^{3}$ КНП «5-та міська клінічна лікарня м. Львова», Львів, Украӥна
}

\section{Резюме}

Вступ. Гострі лімфобластні лейкемії (ГЛЛ) характеризуються різноманітним клінічним перебігом $і$ різною чутливістю до терапії. Враховуючи їх значну поширеність, проводиться інтенсивний пошук нових прогностичних критеріїв, які можуть визначити індивідуальний прогноз та підібрати найоптимальнішу тактику лікування хворих на ГЛЛ.

Метою була оцінка діагностичного та прогностичного значення зміни плоїдності хромосомного набору при ГЛЛ.

Матеріали і методи. Цитогенетичні дослідження клітин периферичної крові (ПК) та/або кісткового мозку (КМ) проведено у 48 пачієнтів з ГЛЛ (хворі віком від 18 до 82 років, серед них 24 чоловіків $і 24$ жінок). Використовували метод класичної цитогенетики та флуоресцентну in situ гібридизацію (FISH). Цитогенетичні дослідження було виконано згідно стандартних методик, а каріотипи - описано відповідно до International System for Human Cytogenetic Nomenclature (ISCN, 2016).

Результати. Виявлено циитогенетичні аномалії різного характеру, які включали $t(9 ; 22)(q 34 ; q 11)$, ген $B C R / A B L$, перебудови 11q23, t(4;11)(q21;q23), del(17p), del(7q), гіпер- та гіподиплоїдний набори хромосом та інші, у 68,8\% хворих на ГЛЛ. Наявність деяких генетичних аномалій (фузійний ген $B C R / A B L$ ) встановлено 
за допомогою молекулярно-генетичного методу (FISH). Високу гіпердиплоїдію (51-67 хромосом) виявлено у 5 (10,4\%) пацієнтів з ГЛЛ. Гіподиплоїдію (24-44 хромосом) виявлено у 2 (4,2\%) випадках. Підтверджено варіант ГЛЛ згідно $з$ класифікацією ВООЗ (2016) у 35,4\% пацієнтів. 3 урахуванням виявлених аномалій хворих на ГЛЛ класифіковано на цитогенетичні групи прогнозу перебігу захворювання: група хворих з несприятливими цитогенетичними маркерами (35,4\%) $(t(9 ; 22)(q 34 ; q 11), t(4 ; 11)(q 21 ; q 23)$, гіподиплоїдний набір хромосом, комплексний каріотип ( $\geq 3$ аномалій)), група проміжного прогнозу без прогностично значущих маркерів (56,3\%) та групу хворих зі сприятливими факторами прогнозу (8,3\%) (t(12;21)(р13;q22), висока гіпердиплоїдія), щуо дозволяє підібрати найоптимальнішу тактику їх лікування.

Висновки. У нашому дослідженні циитогенетичні аномалії різного характеру виявлено у 68,8\% пацієнтів з ГЛЛ. 3 урахуванням виявлених аномалій хворих на ГЛЛ класифіковано на три цитогенетичні групи. Частота виявлення високоі високої гіпердиплоїдї та гіподиплоїдї становила 10,4\% та 4,2\%, відповідно. Цитогенетичні методи повинні бути включені у стандарти обстеження хворих на ГЛЛ для діагностики, прогнозування перебігу та підбору оптимальної тактики лікування. Крім обов'язкового аналізу диференціально-зафарбованих хромосом, у хворих на ГЛЛ необхідно застосовувати молекулярно-генетичні дослідження, $а$ саме: метод FISH, а також полімеразну ланцюгову реакиію (ПЛР).

Ключові слова: гостра лімфобластна лейкемія, каріотип, цитогенетичні аномалї, діагноз, прогноз.

\section{Introduction}

An important but little-studied problem is the detection of hyperploidy and hypoploidy in patients with acute lymphoblastic leukemia (ALL), which determine changes of chromosome set $[1,2]$.

Hyperploid cell clones are classified into subgroups by modal number of chromosomes: low hyperdiploidy (47-50 chromosomes), high hyperdiploidy (51-67 chromosomes), near-triploidy (68-79 chromosomes) and near-tetraploidy (84-100 chromosomes). Low hyperdiploidy (47-50 chromosomes) is seen in $15 \%$ of patients, both children and adults. Trisomies of the chromosomes 8 (10\% of cases), $10(8 \%), 21(39 \%)$ and X (21\%) are usually detected. Neartriploid (68-79 chromosomes) and near-tetraploid (84-100 chromosomes) chromosome sets are found very rarely $[1,2]$.

High hyperdiploidy characterized by the presence of 51-67 chromosomes and observed in $20-30 \%$ of the children with ALL and $5 \%$ of the adult ALL patients. The most common additional chromosomes are: 4 (78\% of cases), 6 (85\%), 10 (63\%), 14 (84\%), 17 (68\%), 18 (76\%), 21 (99\%) and X (89\%). The gains usually present as trisomies (or two copies of the $\mathrm{X}$ chromosome in males). The exceptions are of chromosome 21 , which is tetrasomic in $70 \%$ of patients, and tetrasomies of chromosomes 14 and 18 , which occur in $5 \%$ of 
patients. Structural chromosomal abnormalities are also present not only as a part of the high hyperdiploid karyotype in $50 \%$ of cases, namely abnormalities of 1q (15\% of cases), deletion $6 \mathrm{q}(7 \%)$, isochromosome i(17)(q10) (2\%) and others. The prognosis of ALL with high hyperdiploidy is favorable, although when prognostically unfavorable structural changes are detected as a part of the high hyperdiploid karyotype, it significantly deteriorates [1-4].

Hypodiploidy is defined as the presence of 24-44 chromosomes and is detected in 2-8\% patients with ALL. Hypodiploid cell clones are classified into subgroups by modal number of chromosomes: high hypodiploidy (40-44 chromosomes), low hypodiploidy (30-39 chromosomes), near-haploidy (24-29 chromosomes). Structural chromosomal changes are often observed in addition to the numerical abnormalities. The haploid chromosome set, which is found in $2-3 \%$ of patients with ALL, is characterized, as a rule, only by numerical rearrangements. Most chromosomes are lost and instead of chromosome pairs one homologue remains, two homologues are stored most often in 10, 14, 18, 21 pairs. Hypodiploid chromosome set in ALL is an unfavorable marker of the disease, and near-haploid set - an extremely adverse factor [1, 2, 5-8].

The aim of the study was to detect diagnostic and prognostic significance of chromosome set changes in patients with ALL.

\section{Materials and methods}

Cytogenetic investigations of peripheral blood (PB) and/or bone marrow (BM) cells from 48 patients with ALL were performed. Diagnosis of ALL was fulfilled based on the results of clinical examination, cytological, cytochemical and immunophenotypic investigation of PB and/or BM. Subtypes of ALL were defined according to the FAB classification and the modified WHO classification (2016) of hematopoietic and lymphoid tissue neoplasms, which provides for the wider use of cytogenetic and molecular genetic research methods [9] and to the generally accepted criteria [10, 11]. Patients aged 18 to 82 years were examined, including $24(50 \%)$ men and $24(50 \%)$ women. All patients were hospitalized at hematology departments of the Institute of Blood Pathology and Transfusion Medicine (Lviv, Ukraine) or Municipal Clinical Hospital No. 5 (Lviv, Ukraine). Compliance of the study with bioethical standards was approved by the Ethics Committee of the SI «Institute of Blood Pathology and Transfusion Medicine» (Lviv, Ukraine). All patients provided their consent to the participation in the study.

Conventional method of 24- and 48-hour PB and/or BM cells culture in vitro was used. Conventional cytogenetic methods were carried out using standard techniques which included colcemide action, hypotension, fixation 
and samples preparation [12-14]. Analysis of metaphase chromosomes was performed using the G-technique of differential staining. Samples were analyzed at a magnification of $\times 1000$ under a light microscope Olympus BX41 (Olympus, Japan) using a system for chromosomal analysis CytoVision (Applied Imaging, UK) at the Laboratory of Immunology and Genetics of Blood Neoplasms of SI «Institute of Blood Pathology and Transfusion Medicine»; head of the laboratory - MD, PhD, Senior Research Associate O. O. Shalay, certificate of the laboratory certification No RL 008/19, valid until February 25, 2024. At least 20 metaphase plates were analyzed. The resolution of the analysis was 200-500 segments per haploid set. Karyotypes were analyzed and described according to the International System for Human Cytogenetic Nomenclature - ISCN, 2016 [15].

Molecular cytogenetic method fluorescence in situ hybridization (FISH) with appropriate probe was used additionally when suitable for analysis metaphase plates were absent. Samples preparation and hybridization procedure was carried out by Pinkel et al. [16] taking into consideration the recommendations of the probe manufacturer. Samples were analyzed and microphotographed at a magnification of $\times 1000$ with an appropriate set of light filters under a fluorescence microscope Olympus BX41 (Olympus, Japan) using a system for chromosomal analysis CytoVision (Applied Imaging, UK) at the Laboratory of Immunology and Genetics of Blood Neoplasms. At least 200 cells were analyzed to calculate the percentage of cells with the rearrangement. The results of the FISH analysis were described according to the International System for Human Cytogenetic Nomenclature (ISCN) [15].

\section{Results}

Cytogenetic investigations were performed in 48 patients. Standard cytogenetic method of karyotyping revealed the presence of a complex karyotype with multiple numerical and/or structural changes $(\geq 3)$ in 14 patients, two chromosome abnormalities in 9 patients and one rearrangement - in 10 patients. Among the 14 patients with multiple karyotype changes: 5 patients had high hyperdiploidy (51-67 chromosomes), 2 patients had a hypodiploid karyotype (24-44 chromosomes), 1 patient had a near-triploidy (68-79 chromosomes). In general, cytogenetic abnormalities of different kind were observed in $33(68.8 \%)$ of the 48 examined patients.

Typically, a normal cell clone was also usually detected in patients with ALL in addition to the abnormal cell clone in the research of bone marrow cells. Percent of abnormal cells usually correlated with the percent of blasts in the BM. Such correlation was not detected in the research of PB cells. 
Normal male or female karyotype without cytogenetically visible changes was detected in $15(31.2 \%)$ patients.

Detection of the $B C R / A B L$ fusion gene by molecular cytogenetic method FISH was performed on the interphase nuclei of all patients with ALL. Presence of the $B C R / A B L$ fusion gene was confirmed in 9 patients, while in 39 patients it was disproved.

The most common abnormalities in the examined group of patients with ALL were: Philadelphia $(\mathrm{Ph})$ chromosome formed as a result of translocation between chromosomes 9 and $22-\mathrm{t}(9 ; 22)(\mathrm{q} 34 ; \mathrm{q} 11)$ (9 cases); high hyperdiploidy - 51-67 chromosomes in the karyotype (5 cases); abnormalities $11 \mathrm{q} 23 / K M T 2 A$ (5 cases), namely - translocations $\mathrm{t}(4 ; 11)(\mathrm{q} 21 ; \mathrm{q} 23)$ (3 cases) and $\mathrm{t}(11 ; 14)(\mathrm{q} 23 ; \mathrm{q} 32)$ (1 case) and deletion del(11)(q23) (1 case); hypodiploidy - 24-44 chromosomes in the karyotype (2 cases); deletion of $17 q-\operatorname{del}(17 q)$ ( 2 cases); deletion of $7 q-\operatorname{del}(7 q)$ ( 2 cases).

The results of cytogenetic investigations of leukemic cells in patients with ALL with change of chromosome set are presented in the table.

Table. Results of cytogenetic investigations of leukemic cells from patients with ALL with change of chromosome set

\begin{tabular}{|c|c|c|c|c|}
\hline Case & Sex & $\begin{array}{l}\text { Subtype } \\
\text { of ALL }\end{array}$ & Age & Karyotype \\
\hline 1 & M & $\begin{array}{l}\text { proB- } \\
\text { ALL }\end{array}$ & 82 & $\begin{array}{c}77, \mathrm{XXY}, \mathrm{t}(4 ; 11)(\mathrm{q} 21 ; \mathrm{q} 23) \times 2,+13,+16,+17,+18,+1 \\
9,+20,+21,+22[20]\end{array}$ \\
\hline 2 & $\mathrm{~F}$ & $\begin{array}{l}\text { preB- } \\
\text { ALL }\end{array}$ & 28 & $\begin{array}{l}57, \mathrm{XX},+\mathrm{X},+2,+4,+6,+8, \mathrm{t}(9 ; 22)(\mathrm{q} 34 ; \mathrm{q} 11),+11,+14, \\
\quad+17,+21 \mathrm{x} 2,+\operatorname{der}(22) \mathrm{t}(9 ; 22)(\mathrm{q} 34 ; \mathrm{q} 11)[20]\end{array}$ \\
\hline 3 & M & $\begin{array}{l}\text { common } \\
\text { B-ALL }\end{array}$ & 24 & $\begin{aligned} 56, \mathrm{XY}, \operatorname{der}(1),+3,+4, & +6,+8,+10,+14,+18,+19,+21, \\
& +\operatorname{mar}[20]\end{aligned}$ \\
\hline 4 & M & $\begin{array}{l}\text { proB- } \\
\text { ALL }\end{array}$ & 62 & $\begin{array}{c}62 \sim 66, \mathrm{XY},+\mathrm{X},+1,+2,+3,+4,+5,+6,+8 \times 2,+10,+11 \mathrm{x} \\
2,+12,+13,+14,+15,+16,+17,+18,+19,+20,+21, \\
+22[\mathrm{cp} 20]\end{array}$ \\
\hline 5 & $\mathrm{~F}$ & $\begin{array}{l}\text { preB- } \\
\text { ALL }\end{array}$ & 20 & $\begin{array}{l}60 \sim 61, \mathrm{XX},+\mathrm{X},+1,+3,+4,+6,+8,+9,+10,+11,+14 \\
\quad+15,+17,+18,+21,+\operatorname{mar}[\mathrm{cp} 3] / 46, \mathrm{XX}[18]\end{array}$ \\
\hline 6 & $\mathrm{~F}$ & $\begin{array}{l}\text { common } \\
\text { B-ALL }\end{array}$ & 52 & $\begin{array}{c}62 \sim 67, \mathrm{XX},+2,+3 \times 2,+4,+5,+6,+7,+10,+11,+12 \times 2 \\
+13,+14,+15,+16,+17,+18,+19 \times 2,+20 \times 2,+21, \\
+22[\mathrm{cp} 2] / 46, \mathrm{XX}[18]\end{array}$ \\
\hline 7 & $\mathrm{~F}$ & $\begin{array}{l}\text { proT- } \\
\text { ALL }\end{array}$ & 21 & $43 \sim 44, X X,-18,-20,-21,-22[\mathrm{cp} 20]$ \\
\hline 8 & M & $\begin{array}{l}\text { preT- } \\
\text { ALL }\end{array}$ & 60 & $\begin{array}{c}\text { 41 43,XY,t(1;6)(q32; q27),-7,-10, add(12)(q24), } \\
\operatorname{del}(17)(\mathrm{p} 11), \mathrm{r}(17)(\mathrm{p} 13 \mathrm{q} 25),-13,-14,-15,-16, \\
-17,+\operatorname{mar}[\mathrm{cp} 19] / 46, \mathrm{XY}[4]\end{array}$ \\
\hline
\end{tabular}


The table shows that near-triploidy (68-79 chromosomes) was detected in 1 patient (No. 1), which is $2.1 \%$. Chromosome number in the set was 77 chromosomes. This patient had also structural rearrangement $\mathrm{t}(4 ; 11)(\mathrm{q} 21 ; \mathrm{q} 23)$ in addition to the numerical changes.

High hyperdiploidy (51-67 chromosomes) was detected in 5 patients (No. 2-6), which is $10.4 \%$. Chromosome number in the set ranged from 57 to 67. Among the patients with high hyperdiploidy: 3 patients (No. 4-6) had only numerical changes (Fig. 1), while 2 other patients (No. 2, 3) had also structural rearrangements in addition to the numerical changes. Among them marker abnormality for ALL t $(9 ; 22)(\mathrm{q} 34 ; \mathrm{q} 11)$ (case No. 2) was found.

Hypodiploidy (24-44 chromosomes), as can be seen from the table, was detected in 2 patients (No. 7, 8), which is $4.2 \%$. Chromosome number in the set ranged from 41 to 44 . Among the patients with hypodiploidy: one patient (No/ 7) had only numerical changes (Fig. 2), while other patient (No. 8) had also structural rearrangements in addition to the numerical changes.

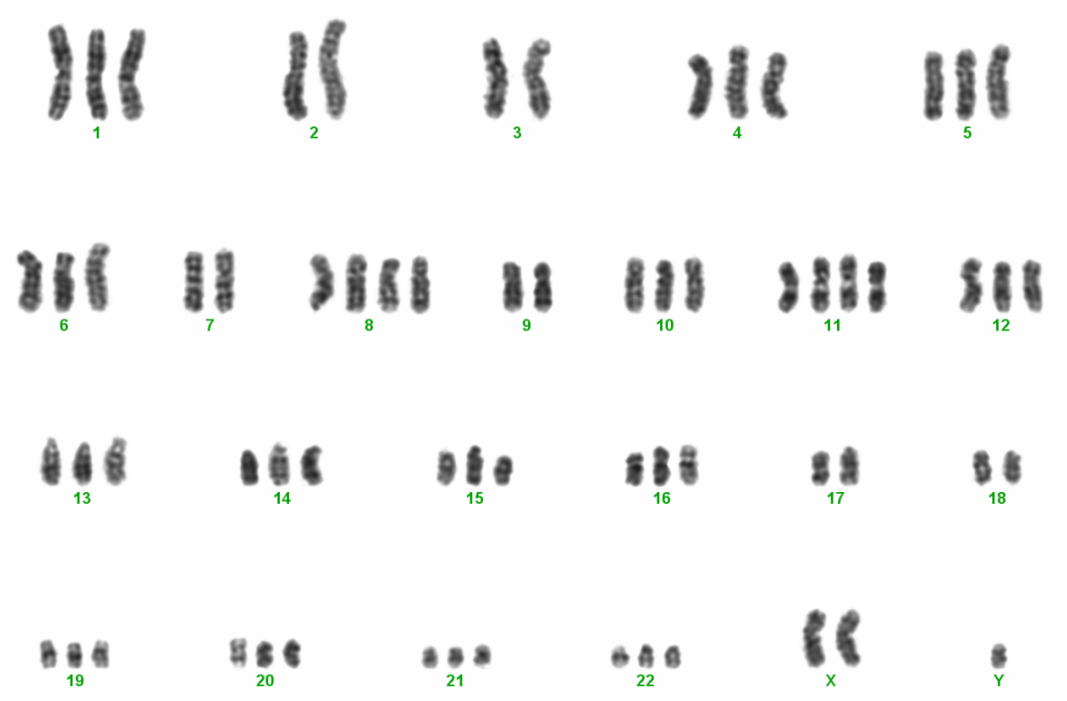

Figure 1. Karyotype with $65, X Y,+X,+1,+4,+5,+6,+8 x 2,+10,+11 \times 2$, $+12,+13,+14,+15,+16,+19,+20,+21,+22$ (No 4) 


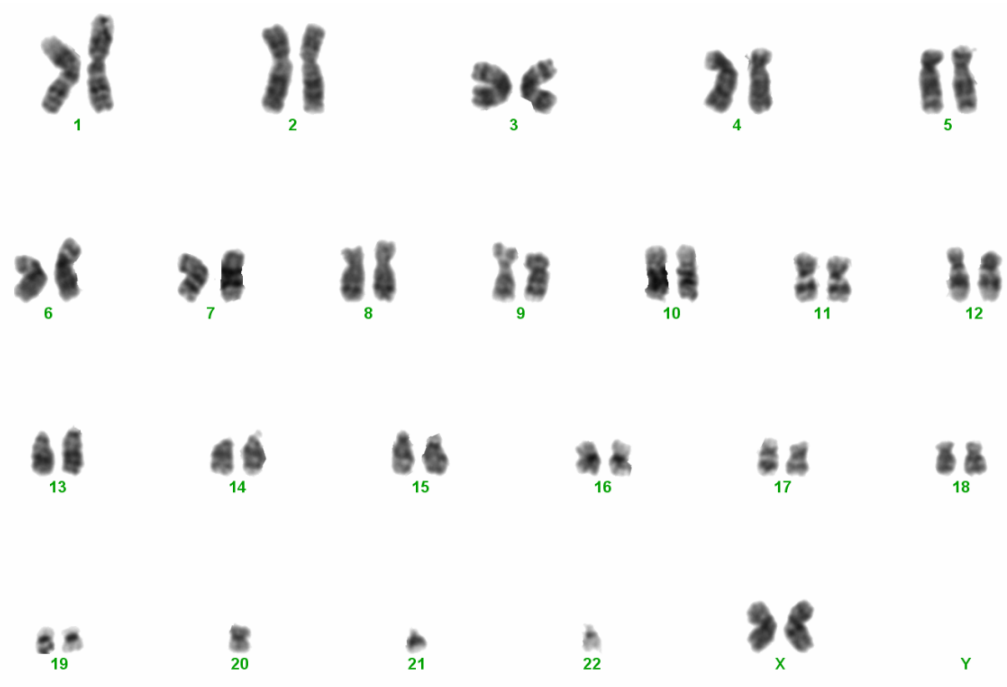

Figure 2. Karyotype with 43,XX,-20,-21,-22 (No. 7)

\section{Discussion}

The spectrum of cytogenetic and molecular genetic abnormalities at different phases of ALL (at diagnosis, at relapse and in remission) is becoming increasingly diagnostic and has a prognostic value for the selection of optimal treatment for the patients. Cytogenetic investigations are needed to establish, confirm or refute diagnosis, as well as to conduct a differential diagnosis of ALL and make a prognosis its course. This is possible due to the presence of characteristic genetic marker abnormalities, some of which can be both diagnostic and prognostic markers. They can be detected by both karyotyping and FISH analysis. The effect of drugs can be more accurately assessed by cytogenetic investigations. The appearance of cells with a normal karyotype indicates its elimination. Complete normalization of the karyotype indicates the presence of cytogenetic remission. Therefor cytogenetic methods acquire special value at application of modern drugs of target action. Detection of new changes in existing cell clone or new abnormal clones is a marker of ALL progression and signals the need to modify the treatment regimen. Recurrence of cells with an abnormal karyotype after achieving cytogenetic remission is 
one of the signs of relapse. It is very important to perform cytogenetic investigations in newly diagnosed patients, because it will not be known later whether the abnormalities were detected initially, whether they arose during the evolution of the disease or induced by treatment.

Based on literature data, clonal chromosomal rearrangements of various kinds are found in $60-85 \%$ of adult patients with ALL [1,2]. It should be noted that karyotype abnormalities were observed in $68.8 \%$ of patients with ALL in the investigated subgroup of patients in acute stage of the disease (48 cases), which is comparable to the data reported in the literature. In general, the following diagnostic abnormities were revealed in the examined group of patients with ALL, namely translocations $\mathrm{t}(4 ; 11)(\mathrm{q} 21 ; \mathrm{q} 23)$ and $\mathrm{t}(9 ; 22)(\mathrm{q} 34 ; \mathrm{q} 11)$, $B C R / A B L$ fusion gene, high hyperdiploidy (51-67 chromosomes), hypodiploidy (24-44 chromosomes) and confirmed the type of ALL according to the WHO classification, 2016 [9] in $37.5 \%$ of patients. These characteristic (recurrent) genetic abnormalities are predicted by the WHO classification. They have a certain prognosis and features of therapy.

High hyperdiploidy characterized by the presence of 51-67 chromosomes is observed in 20-30\% of children with ALL and $5 \%$ adult ALL patients. In our study high hyperdiploidy was found in 6 patients (all patients with B-cell ALL), which was $10.4 \%$ and is slightly higher than reported in the literature [1-4]. It may be due to a small sample of patients. The most common additional chromosomes are: 4 (78 \% of cases), 6 (85\%), 10 (63\%), 14 (84\%), 17 (68\%), 18 $(76 \%), 21(99 \%)$ and $\mathrm{X}(89 \%)$ [1-4], which is confirmed in our patients. Structural chromosomal abnormalities are also present as a part of the high hyperdiploid karyotype in $50 \%$ of cases, namely abnormalities of $1 \mathrm{q}(15 \%$ of cases), deletion 6q (7\%), isochromosome i(17)(q10) (2\%) and others [1-4]. We detected additional structural cytogenetic abnormalities in $3(60 \%)$ of the 5 examined patients with high hyperdiploidy, namely $\operatorname{der}(1 \mathrm{q}), \mathrm{t}(4 ; 11)(\mathrm{q} 21 ; \mathrm{q} 23)$, $\mathrm{t}(9 ; 22)(\mathrm{q} 34 ; \mathrm{q} 11),+\operatorname{der}(22) \mathrm{t}(9 ; 22)(\mathrm{q} 34 ; \mathrm{q} 11)$. The prognosis of ALL with high hyperdiploidy is favorable, although when prognostically unfavorable structural changes, namely $\mathrm{t}(4 ; 11)(\mathrm{q} 21 ; \mathrm{q} 23)$ or $\mathrm{t}(9 ; 22)(\mathrm{q} 34 ; \mathrm{q} 11)$, are detected as a part of the hyperpdiloid karyotype, it significantly deteriorates [1-4]. We detected unfavorable marker rearrangement $\mathrm{t}(9 ; 22)(\mathrm{q} 34 ; \mathrm{q} 11)$ in $1(20 \%)$ of the 5 examined patients with high hyperdiploidy. In our investigation median survival of all ALL patients with high hyperdiploidy was 26 months. However survival of patient with high hyperdiploidy and $t(9 ; 22)(\mathrm{q} 34 ; \mathrm{q} 11)$ was only 2 month.

Hypodiploidy characterized by the presence of 24-44 chromosomes was detected in 2-8\% patients with ALL. In our study hypodiploidy was found in 2 patients (all patients with T-cell ALL), rate was $4.2 \%$, which is comparable 
to the data reported in the literature [1, 2, 5-8]. Structural chromosomal changes are often observed in addition to the numerical abnormalities [1, 2, 58 ], which was found in our study in $1(50 \%)$ of 2 examined patients with hypodiploidy. Based on literature data, such chromosomes set in ALL is an unfavorable marker of the disease, and near haploid set - an extremely adverse factor $[1,2,5-8]$. In our investigation median survival of ALL patients with hypodiploidy was 2 months.

The obtained results of cytogenetic analysis allowed classify patients with ALL into three prognosic groups taking into consideration the recommendations of European LeukemiaNet [17-20]: the group of patients with adverse cytogenetic markers, the intermediate risk group without significant prognostic markers and the group with favorable prognostic factors. The first group included 17 ALL cases $(35.4 \%)$ with adverse cytogenetic markers, namely 9 patients with $\mathrm{t}(9 ; 22)(\mathrm{q} 34 ; \mathrm{q} 11), 3$ patients with $\mathrm{t}(4 ; 11)(\mathrm{q} 21 ; \mathrm{q} 23), 2$ patients with hypodiploidy and 3 patients with other multiple cytogenetic changes. The second group included 27 ALL cases $(56.3 \%)$ with intermediate prognostic markers, namely 12 patients with rare or atypical chromosomal changes and 15 patients with normal karyotype. The latter group included 4 patients $(8.3 \%)$ with favorable prognostic factors, namely cases with high hyperdiploidy. One patient with high hyperdiploidy were not included in this group because her had adverse prognostic marker $\mathrm{t}(9 ; 22)(\mathrm{q} 34 ; \mathrm{q} 11)$ as a part of the hyperdiploid karyotype. She was included in the first risk group.

Kaplan-Meier cumulative survival curves of ALL patients in groups with adverse cytogenetic markers (Group 1), intermediate prognostic markers (Group 2) and favorable cytogenetic factors (Group 3) were constructed (Fig. 3). Median survival of ALL patients was: 4 months for patients with adverse cytogenetic markers, 8 months for patients with intermediate prognostic markers and 26 months for patients with favorable cytogenetic factors. The survival difference of patients from Group 1 and Group $2(\mathrm{p}=0,361$; log-rank test), Group 1 and Group 3 ( $\mathrm{p}=0,63$; log-rank test), Group 2 and Group 3 $(\mathrm{p}=0,131$; log-rank test) was not statistically significant, which may be due to a small sample of patients.

Distribution of patients into risk groups according to the identified prognostic markers allowed to choose the most appropriate treatment approach for them, namely the intensity of therapy, the necessity of bone marrow transplantation in the first remission, the necessity of the prescription of tyrosine kinase inhibitors for ALL patients with $\mathrm{t}(9 ; 22)(\mathrm{q} 34 ; \mathrm{q} 11)$ and/or the corresponding $B C R / A B L$ fusion gene. 


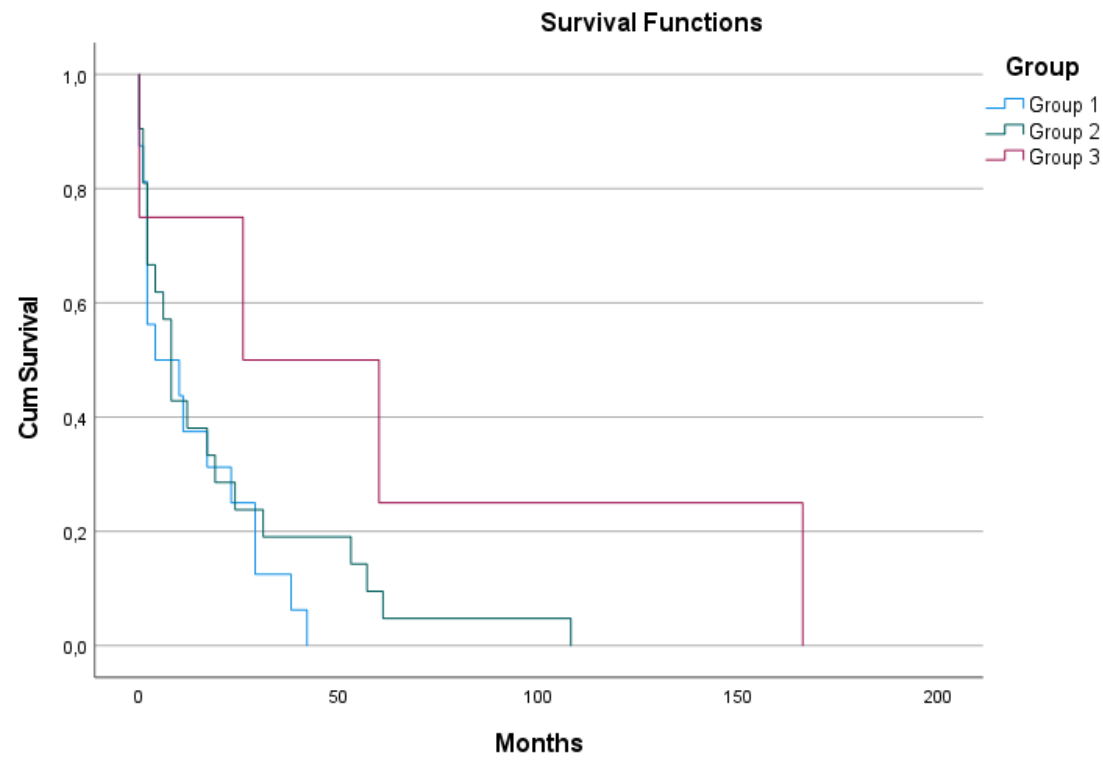

Figure 3. Kaplan-Meier cumulative overall survival curves of ALL patients in groups with adverse cytogenetic markers (Group 1), intermediate prognostic markers (Group 2) and favorable cytogenetic factors (Group 3)

Chi-square $=3,998, d f=2, p=0,135$; Group 1 vs Group 2 -log-rank test; $p=0,361$;

Group 1 vs Group 3 -log-rank test; $p=0,63$; Group 2 vs Group 3 -log-rank test;

$$
p=0,131
$$

\section{Conclusions}

Cytogenetic investigations allowed to detect ALL-associated cytogenetic abnormalities of various kind, which included $\mathrm{t}(9 ; 22)(\mathrm{q} 34 ; \mathrm{q} 11), B C R / A B L$ gene, $11 \mathrm{q} 23$ rearrangements, $\mathrm{t}(4 ; 11)(\mathrm{q} 21 ; \mathrm{q} 23)$, del $(17 \mathrm{p})$, del(7q), hyperdiploidy and hypodiploidy and others in $68.8 \%$ of patients with ALL. High hyperdiploidy (51-67 chromosomes) was detected in $5(10.4 \%)$ patients. Hypodiploidy (24-44 chromosomes) was detected in 2 (4.2\%) cases. Median survival of ALL patients with high hyperdiploidy and hypodiploidy was 26 and 2 months respectively. Taking into consideration the identified cytogenetic abnormalities, namely $\mathrm{t}(9 ; 22)(\mathrm{q} 34 ; \mathrm{q} 11), B C R / A B L$ gene, $\mathrm{t}(4 ; 11)(\mathrm{q} 21 ; \mathrm{q} 23)$, hyperdiploidy and hypodiploidy, the type of ALL was confirmed according to the WHO classification (2016) in $37.5 \%$ of patients. Based on cytogenetic investigations ALL patients were classified into prognostic groups: the groups 
of patients with adverse prognosis factors (35.4\%) ( $\mathrm{t}(9 ; 22)(\mathrm{q} 34 ; \mathrm{q} 11)$, $\mathrm{t}(4 ; 11)(\mathrm{q} 21 ; \mathrm{q} 23)$, hypodiploidy, complex karyotype ( $\geq 3$ abnormalities)); the intermediate-risk group without significant cytogenetic markers $(56.3 \%)$ (rare or atypical chromosomal rearrangements, normal karyotype) and the groups of patients with favorable prognostic markers $(8.3 \%)(\mathrm{t}(12 ; 21)(\mathrm{p} 13 ; \mathrm{q} 22)$, high hyperdiploidy. Median survival of ALL patients was: 4 months for patients with adverse cytogenetic markers, 8 months for patients with intermediate prognostic markers and 26 months for patients with favorable cytogenetic factors. Cytogenetic investigations should be included in the standard examination of patients with ALL for diagnosis, prognosis and selection the optimal treatment strategy. Besides the analysis of differential banding pattern chromosomes, it is necessary for patients with ALL to apply molecular genetic studies, namely FISH and polymerase chain reaction (PCR).

\section{Література}

1. Ольшанская Ю.В., Домрачева Е.В. Хромосомные перестройки при острых лейкозах. Москва: МЕДпрессинформ, 2006. $112 \mathrm{c}$.

2. Heim S., Mitelman F. Cancer Cytogenetics. 4 ed. NY: Wiley-Blackwell; 2015. $648 \mathrm{p}$. https://doi.org/10.1002/9781118795569

3. Paulsson K., Johansson B. High hyperdiploid childhood acute lymphoblastic leukemia. Genes Chromosomes Cancer. 2009; 48(8):637-60. https://doi.org/10.1002/gcc.20671.

4. Chen Z., Sun Y., Xie W., Wang S.A, $\mathrm{Hu}$ S., Li S., et al. Is hyperdiploidy a favorable cytogenetics in adults with B-lymphoblastic leukemia? Cancer Medicine. 2019; 8:4093-9. https://doi.org/10.1002/cam4.2255

5. Safavi S., Olsson L., Biloglav A., Veerla S., Blendberg M., Tayebwa J., et al. Genetic and epigenetic characterization of hypodiploid acute lymphoblastic leukemia. Oncotarget. 2015; 6(40):42793-802.

https://doi.org/10.18632/oncotarget.6000

\section{References}

1. Olshanskaya Yu.V., Domracheva E.V. Chromosomal rearrangements in acute leukemias. Moscow: MEDpressinform; 2006. $122 \mathrm{p}$.

2. Heim S., Mitelman F. Cancer Cytogenetics. 4 ed. NY: Wiley-Blackwell; 2015. $648 \mathrm{p}$. https://doi.org/10.1002/9781118795569

3. Paulsson K., Johansson B. High hyperdiploid childhood acute lymphoblastic leukemia. Genes Chromosomes Cancer. 2009; 48(8):637-60. https://doi.org/10.1002/gcc.20671.

4. Chen Z., Sun Y., Xie W., Wang S.A, $\mathrm{Hu}$ S., Li S., et al. Is hyperdiploidy a favorable cytogenetics in adults with B-lymphoblastic leukemia? Cancer Medicine. 2019; 8:4093-9. https://doi.org/10.1002/cam4.2255

5. Safavi S., Olsson L., Biloglav A., Veerla S., Blendberg M., Tayebwa J., et al. Genetic and epigenetic characterization of hypodiploid acute lymphoblastic leukemia. Oncotarget. 2015; 6(40):42793-802. https://doi.org/10.18632/oncotarget.6000 
6. Safavi S., Paulsson K. Near-haploid and low-hypodiploid acute lymphoblastic leukemia: two distinct subtypes with consistently poor prognosis. Blood. 2017; 129(4):420-3. https://doi.org/10.1182/blood-201610-743765

7. Carroll A.J., Heerema N.A., GastierFoster J.M., Astbury C., Pyatt R., Reshmi S.C., et al. Masked hypodiploidy: hypodiploid acute lymphoblastic leukemia (ALL) in children mimicking hyperdiploid ALL: a report from the Children's Oncology Group (COG) AALL03B1 study. Blood. 2009; 114(22):1580. https://doi.org/10.1182/blood.V114. 22.1580 .1580

8. Comeaux E.Q., Mullighan C.G. TP53 Mutations in hypodiploid acute lymphoblastic leukemia. Cold Spring Harb. Perspect Med. 2017; 7(3): a026286.

https://doi.org/10.1101/cshperspect. a026286

9. Arber D.A., Orazi A., Hasserjian R., Thiele J., Borowitz M.J., Le Beau M.M., et al. The 2016 revision to the World Health Organization classification of myeloid neoplasms and acute leukemia. Blood. 2016; 127(20): 2391-405.

https://doi.org/10.1182/blood-201603-643544

10. Виговська Я.І., Новак В.Л. Стандарти в гематології. Львів: Кварт; 2002. $165 \mathrm{c}$.

11. Матлан В.Л., Шпарик Я.В. Онкогематологія: Класифікації. Клінічні рекомендації. Режим медикаментозної терапії. Львів: Галицька видавнича спілка; 2009. 180 с.

12. Андреєва С.В., Дроздова В.Д. Стандарти аналізу препаратів
6. Safavi S., Paulsson K. Near-haploid and low-hypodiploid acute lymphoblastic leukemia: two distinct subtypes with consistently poor prognosis. Blood. 2017; 129(4):420-3. https://doi.org/10.1182/blood-201610-743765

7. Carroll A.J., Heerema N.A., GastierFoster J.M., Astbury C., Pyatt R., Reshmi S.C., et al. Masked hypodiploidy: hypodiploid acute lymphoblastic leukemia (ALL) in children mimicking hyperdiploid ALL: a report from the Children's Oncology Group (COG) AALL03B1 study. Blood. 2009; 114(22):1580.

https://doi.org/10.1182/blood.V114. 22.1580.1580

8. Comeaux E.Q., Mullighan C.G. TP53 Mutations in hypodiploid acute lymphoblastic leukemia. Cold Spring Harb. Perspect Med. 2017; 7(3): a026286.

https://doi.org/10.1101/cshperspect. a026286

9. Arber D.A., Orazi A., Hasserjian R., Thiele J., Borowitz M.J., Le Beau M.M., et al. The 2016 revision to the World Health Organization classification of myeloid neoplasms and acute leukemia. Blood. 2016; 127(20): 2391-405.

https://doi.org/10.1182/blood-201603-643544

10. Vyhovska Ya.I., Novak V.L. Standards in hematology. Lviv: Quart; 2002. $165 \mathrm{p}$.

11. Matlan V.L., Shparyk Ya.V. Oncohematology: Classifications. Clinical recommendations. Drug therapy regimen. Lviv: Galician Publishing Union; 2009. 180 p.

12. Andreyeva S.V., Drozdova V.D. Standard of analysis of chromosome 
хромосом при неоплазіях кровотворення (методичні рекомендаціі). Київ; 2007. 44 с.

13. Wan T.S.K. Cancer Cytogenetics. Methods and Protocols. Methods in Molecular Biology. NY: Humana Press; 2017. 340 p. https://doi.org/10.1007/978-1-49396703-2

14. Haferlach C., Rieder H., Lillington D.M., Dastugue N., Hagemeijer A., Harbott J., et al. Proposals for standardized protocols for cytogenetic analyses of acute leukemias, chronic lymphocytic leukemia, chronic myeloid leukemia, chronic myeloproliferative disorders, and myelodysplastic syndromes. Genes Chromosomes Cancer. 2007; 46(5):494-9. https://doi.org/10.1002/gcc.20433

15. McGowan-Jordan J., Simons A., Schmid M. An International System for Human Cytogenetic Nomenclature. Basel: S. Karger; 2016. 140 p. https://doi.org/10.1159/isbn.978-3318-06861-0

16. Pinkel D., Straume T., Gray J.W. Cytogenetic analysis using quantitative high sensitivity, fluorescence hybridization. Proceedings of the National Academy of Sciences of the USA. 1986; 83(9):2934-8. https://doi.org/10.1073/pnas.83.9.2934

17. Rack K.A., van den Berg E., Haferlach C., Beverloo H.B., Costa D., Espinet B., et al. Cytogenetics and molecular genetics European recommendations and quality assurance for cytogenomic analysis of hematological neoplasms. Leukemia. 2019; 33(8):1851-67. https://doi.org/10.1038/s41375-0190378-z preparations in hematopoietic neoplasms (guidelines). Kyiv; 2007. $44 \mathrm{p}$.

13. Wan T.S.K. Cancer Cytogenetics. Methods and Protocols. Methods in Molecular Biology. NY: Humana Press; 2017. 340 p.

https://doi.org/10.1007/978-1-49396703-2

14. Haferlach C., Rieder H., Lillington D.M., Dastugue N., Hagemeijer A., Harbott J., et al. Proposals for standardized protocols for cytogenetic analyses of acute leukemias, chronic lymphocytic leukemia, chronic myeloid leukemia, chronic myeloproliferative disorders, and myelodysplastic syndromes. Genes Chromosomes Cancer. 2007; 46(5):494-9. https://doi.org/10.1002/gcc.20433

15. McGowan-Jordan J., Simons A., Schmid M. An International System for Human Cytogenetic Nomenclature. Basel: S. Karger; 2016. 140 p. https://doi.org/10.1159/isbn.978-3318-06861-0

16. Pinkel D., Straume T., Gray J.W. Cytogenetic analysis using quantitative high sensitivity, fluorescence hybridization. Proceedings of the National Academy of Sciences of the USA. 1986; 83(9):2934-8. https://doi.org/10.1073/pnas.83.9.2934

17. Rack K.A., van den Berg E., Haferlach C., Beverloo H.B., Costa D., Espinet B., et al. Cytogenetics and molecular genetics European recommendations and quality assurance for cytogenomic analysis of hematological neoplasms. Leukemia. 2019; 33(8):1851-67. https://doi.org/10.1038/s41375-0190378-z 
18. Gokbuget N. Recommendations of the European Working Group for Adult ALL.1st edition. BremenLondon-Boston: UNI-MED Verlag AG; 2011. 208 p.

19. Hoelzer D., Bassan R., Dombret H., Fielding A., Ribera J.M., Buske C. Acute lymphoblastic leukaemia in adult patients: ESMO Clinical Practice Guidelines for diagnosis, treatment and follow-up. Annals of Oncology. 2016; 27(5):v69-v82. https://doi.org/10.1093/annonc/mdw025

20. Rowe J.M. Prognostic factors in adult acute lymphoblastic leukaemia. British Journal of Haematology. 2010; 150:389-405. https://doi.org/10.1111/j.13652141.2010.08246.x

Стаття надійшла 02.08.2021 Контакти:Inkzotova@gmail.com
18. Gokbuget N. Recommendations of the European Working Group for Adult ALL.1st edition. BremenLondon-Boston: UNI-MED Verlag AG; 2011. 208 p.

19. Hoelzer D., Bassan R., Dombret H., Fielding A., Ribera J.M., Buske C. Acute lymphoblastic leukaemia in adult patients: ESMO Clinical Practice Guidelines for diagnosis, treatment and follow-up. Annals of Oncology. 2016; 27(5):v69-v82. https://doi.org/10.1093/annonc/mdw025

20. Rowe J.M. Prognostic factors in adult acute lymphoblastic leukaemia. British Journal of Haematology. 2010; 150:389-405. https://doi.org/10.1111/j.13652141.2010.08246.x 